\title{
Circulating Circular RNAs: Novel Biomarkers for Heart Failure
}

\author{
Chuan Sun, Mingming Ni, Bo Song and Lu Cao* \\ Department of Pharmacy, Children's Hospital of Nanjing Medical University, Nanjing, China
}

Heart failure (HF) is a serious, chronic disease, causing significant ill health and high mortality worldwide. The current clinical strategies emphasize reducing the transition from a healthy to a failing heart despite the shift in the clinical goal from healing to disease prevention. Recent research advancements on noncoding RNAs (ncRNAs) have demonstrated that circular RNAs (circRNAs) are significant therapeutic targets in HF. Previous studies have highlighted the potential applicability of circRNAs in the diagnosis

OPEN ACCESS

Edited by:

Liberato Berrino,

University of Campania Luigi Vanvitelli,

Italy

Reviewed by:

Chen Chen,

Huazhong University of Science and

Technology, China

Alexander E. Berezin,

Zaporizhia State Medical University,

Ukraine

Juan Francisco Gómez, Universitat Politècnica de València,

Spain

*Correspondence:

Lu Cao

njcaolu@126.com

Specialty section:

This article was submitted to Cardiovascular and Smooth

Muscle Pharmacology,

a section of the journal

Frontiers in Pharmacology

Received: 09 May 2020 Accepted: 21 September 2020 Published: 13 November 2020

Citation:

Sun C, Ni M, Song B and Cao L (2020)

Circulating Circular RNAs: Novel

Biomarkers for Heart Failure.

Front. Pharmacol. 11:560537.

doi: 10.3389/fphar.2020.560537 and treatment of diseases. However, less is known regarding the potential benefits of circRNAs as novel diagnostic and treatment biomarkers for HF. In the present study, we summarize the current developments and achievements associated with the use of circRNAs as HF biomarkers. We also discuss future research directions regarding HF diagnosis and treatment.

Keywords: heart failure, circRNAs, diagnosis biomarkers, exosome, non-coding RNA

\section{INTRODUCTION}

Heart failure (HF) is attributed to several cardiovascular diseases (CVDs), including, cardiac hypertrophy, myocardial fibrosis, and ischemic cardiomyopathy. In 2000, the prevalence of chronic heart failure (CHF) in the Chinese population aged 35-74 years was $0.9 \%$, and CHF prevalence was found to significantly increase with age. The China Heart Failure Patient Registration Research (China-HF) analyzed data from 8516 patients with HF admitted in 88 participating hospitals from 2012 to 2014 and reported a significant increase in the average age of patients hospitalized with HF. Hypertension and coronary heart disease are reported as the main causes of HF in China, and infections have been implicated in the pathogenesis of HF. Currently, the mortality rate after hospitalization with HF is $4.1 \%$ in China from 2014 to 2018, which is significantly lower than the rate in previous years. Patients with HF present with nonspecific symptoms and are difficult to distinguish from those of other cardiovascular diseases. Some of the symptoms presented by patients with HF include dyspnea, orthopnea, and paroxysmal nocturnal dyspnea. In addition, the lack of adequate cardiac output can cause fatigue, weakness, and exercise intolerance. The clinical diagnosis of HF based on clinical manifestations is challenging and may lead to a definitive diagnosis and delayed treatment, thereby causing inaccurate prognosis (Gaggin and Januzzi, 2013).

Consequently, accurate and effective diagnostic measures are needed in clinical practice to distinguish HF from other cardiovascular diseases. Currently, medical history, physical examination, and chest X-rays are the traditional clinical assessment approaches for patients suspected to have HF. However, isolated signs and symptoms cannot be objectively assessed for HF diagnosis (Di Marca et al., 2018). With recent advances in medical technology, noninvasive imaging techniques, such as echocardiography and radionuclide angiography are being used to determine 
ventricular ejection fraction, diastolic function, and chamber pressures that may help diagnose HF. HF can be categorized as either asymptomatic or congestive HF. Patients with asymptomatic HF have ventricular diastolic dysfunction and abnormal ejection fraction with no accompanying clinical symptoms (Naji et al., 2017), further complicating $\mathrm{HF}$ diagnosis. Although the use of both noninvasive and invasive methods to examine HF is relatively accurate, patients with abnormal laboratory examinations may not present $\mathrm{HF}$ symptoms as previously demonstrated, which may confuse patients. Therefore, the development of novel biomarkers can predict and diagnose HF, risk stratification of patients with HF, and even serve as therapeutic targets are of biological significance (Gaggin and Januzzi, 2013).

\section{LIMITATIONS OF CLINICALLY USED BIOMARKERS}

B-type natriuretic peptide (BNP) and N-terminal proBNP (NTproBNP) have been widely used as diagnostic biomarkers for $\mathrm{HF}$ (Cao et al., 2019). In addition, the American Heart Association/ American College of Cardiology (AHA/ACC) and European Society of Cardiology (ESC) guidelines recommend the use of BNP and NT-proBNP for clinical diagnosis of HF (Ponikowski et al., 2016; Yancy et al., 2017). However, diagnosing HF only depending on the concentrations of BNP and NT-proBNP are not accurate enough. Numerous factors can influence the concentrations of BNP and NT-proBNP (Nevo et al., 2011). For example, renal failure affects the metabolism of the two biomarkers and then increases their concentration (Medvedeva et al., 2017). In addition, BNP and NT-proBNP may be influenced by low specificity and fluctuations in circulation levels, including obesity, pulmonary embolism, patients' age, and sex (Metra and Teerlink, 2017; Salgado-Somoza et al., 2017). Therefore, AHA/ACC and ESC guidelines do not recommend biomarker-guided therapy in the management of HF patients (Scali et al., 2014). Combining the concentrations of BNP and NT-proBNP with clinical syndrome, bio-humoral (such as renal function), and echocardiographic assessment may be much more accurate, but it also would delay the diagnosis of $\mathrm{HF}$.

\section{THE POTENTIAL ROLES OF MIRNAS AND LNCRNAS AS BIOMARKERS OF HF}

Over the last few years, the noncoding RNAs have attracted significant interest in the scientific community. High-throughput RNA-sequencing analysis of the genome has shown that $70 \%$ of the human genome is transcribed, but only $2 \%$ code for proteins (Keiner et al., 2013). Regulatory noncoding RNAs are important members of the noncoding RNA family, including microRNAs (miRNAs), long noncoding RNAs (lncRNAs), and circular RNAs (circRNAs). (The noncoding RNA family is shown in Figure 1). MiRNAs are a class of noncoding RNAs approximately 22 nucleotides in length and act as negative regulators of gene expression by binding to the 3' UTR of mRNAs (Khalil et al., 2009). lncRNAs are more than 200 nucleotides in length and rarely exhibit any protein-coding potential. MiRNAs are distributed in both the nucleus and cytoplasm, where they control chromosome modification and inhibit transcription. LncRNAs are distributed in the cytoplasm, where they target mRNAs and regulate the expression of target
A

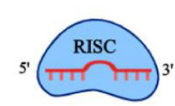

B

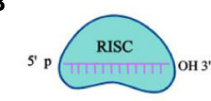

C

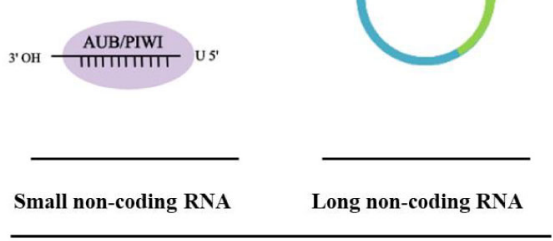

Regulatory non-coding RNA

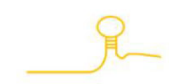

E

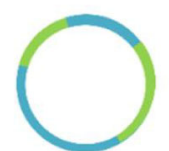

Long non-coding RNA
G

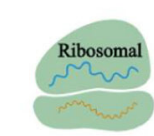

H

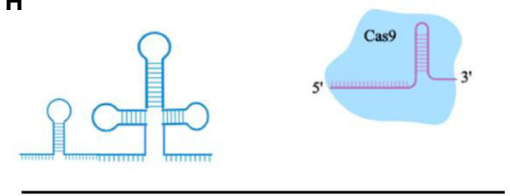

Houskeeping non-coding RNA

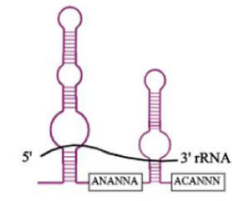

Non-coding RNAs

FIGURE 1 | The noncoding RNA family. (A) microRNAA: miRNA, 19-23 bp. (B) Piwi-interacting RNA: piRNA, 24-30 bp. (C) Small interfering RNA: siRNA, $21-25$ bp. (D) Long noncoding RNA: IncRNA, > 200 bp, linear. (E) Circular RNA: circRNA, > 200 bp, circular. (F) Transfer RNA: tRNA, 74-95 bp. (G) Ribosomal RNA: rRNA, 1215000 bp. (H) Small nuclear RNA: snRNA, 100-300 bp. (I) Small nucleolar RNA: snoRNA, 100-300 bp (i.e. H/ACA box snoRNA). (J) Guide RNA: gRNA, 55-70 bp. 
genes at the transcription level (Czubryt et al., 2003; Backs et al., 2006) or inhibit the function of miRNAs through combined targeting (Vega et al., 2004). The primary mechanisms of miRNAs and lncRNAs are summarized in Figure 2. As the regulatory noncoding RNAs, miRNAs and lncRNAs are shown to play significant roles in regulating CVDs (Wang et al., 2014; Viereck et al., 2016; Chu et al., 2018; Liu et al., 2018), also including HF (Gomes et al., 2020). Additionally, certain noncoding RNAs are stable in the blood, and their altered expression represents various disease states, indicating that they may function as significant CVD biomarkers, including HF. The relative research findings are summarized and shown in Tables 1 and 2.

\section{CIRCRNAS IN HF}

Over the past few years, research on noncoding RNAs implicated in the pathogenesis of HF has rapidly progressed and is still ongoing. Similar to miRNAs and lncRNAs, circRNAs are a class of noncoding RNAs, but unlike linear RNAs, circRNAs form a closed continuous loop, signifying that the structure has neither 5' caps nor 3' tails (Chen and Yang, 2015). circRNAs are primarily produced by exons or introns, and reverse complements or RNA-binding proteins (RBPs) are required for its "life-forms" (Liang and Wilusz, 2014; Vicens and Westhof, 2014; Petkovic and Muller, 2015). As functional noncoding RNAs, the finding of circRNAs has undergone a similar process of those in miRNAs and IncRNAs, from molecular flukes or products of aberrant RNA splicing to research hot spots on the subject of RNA. Although the structure, biogenesis, and functioning of circRNAs need to be studied further, it is still possible to deduce their pathological and physiological functions. CircRNAs function as sponges for miRNAs to regulate the expression of target genes (Hansen et al., 2013; Memczak et al., 2013) and directly regulate transcription with RNA Pol II or protein coding (Ashwal-Fluss et al., 2014; Chen, 2016; Yang et al., 2017). The key mechanisms of circRNAs are summarized in Figure 3. Increasing evidence has revealed the functions of naturally occurring or regulatory circRNAs in the development of cardiovascular diseases, including cardiac hypertrophy, acute myocardial infarction, cardiac cell senescence, and diabetic cardiomyopathy (Wang et al., 2016; Du et al., 2017; Xia and Song, 2020; Zhang Q. et al., 2020).

CircRNAs involved in HF are widely discussed. (This information is described in Table 3 ). The circRNA-miRNAmRNA axis is an important regulatory mechanism in HF. CircSlc8al, a circRNA that is highly expressed in cardiomyocytes (Tan et al., 2017) and highly conserved across vertebrate species, is proven to regulate $\mathrm{HF}$ as an endogenous miRNA sponge (Lim et al., 2019). RNA pull-down and qPCR analysis shows miR-133 and miR-1 were detected to be circSlc8a1-bound. Next, a luciferase assay and biotin-based pull-down assay shows that there was a robust endogenous interaction between circSlc8al with miR-133a and not miR-1 although the circSlc8al sequence contains a putative binding site for miR-1. Forced circSlc8al expression in mouse heart via an AAV9-based vector system would result in HF via regulating the expression of serum response factor (Srf), connective tissue growth factor (CTGF), $\beta 1$-adrenergic receptor ( $\beta 1-\mathrm{AR})$ via miR-133a or adenylate cyclase 6 (Adcy6) directly. Interestingly, the expression of Adcy6 is also affected by circ-HPIK3 (Deng et al., 2019). Overactivation of $\beta$-AR can improve heart function temporarily via regulating $\mathrm{Ca}^{2+}$ load and transient (Morgan et al., 1990; Reiken et al., 2003) but will be a risk factor of HF long term. Deng et al.

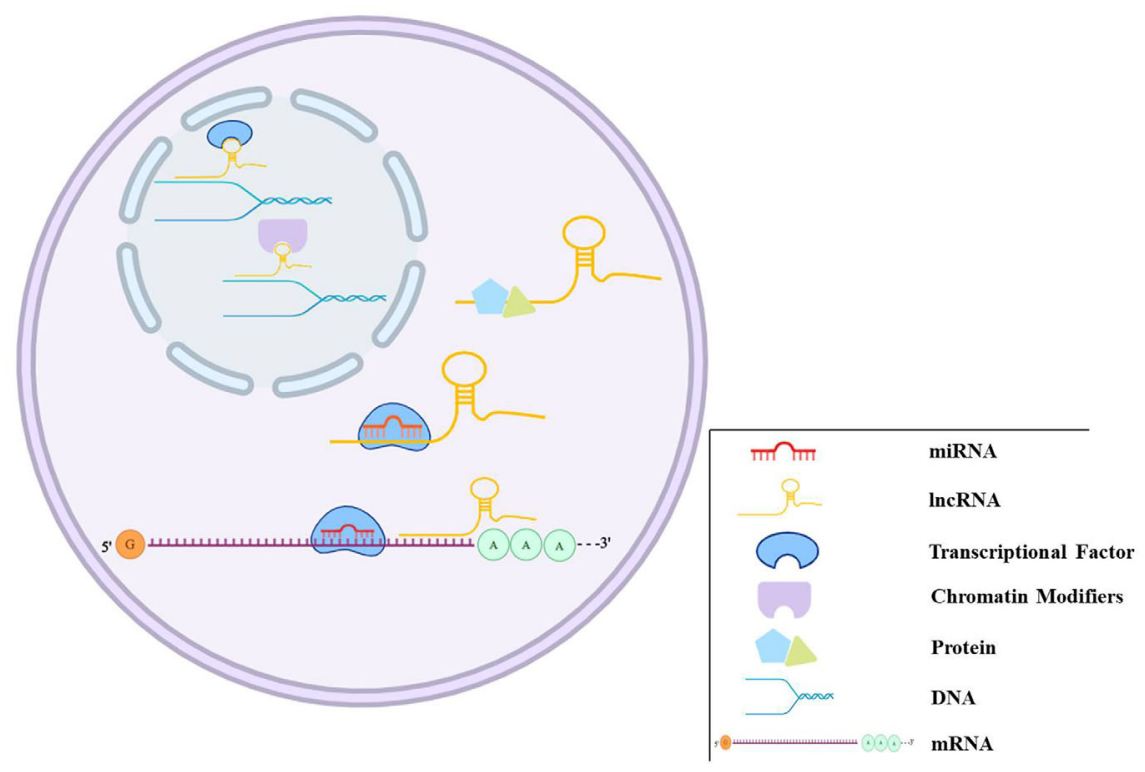

FIGURE 2 | The regulation mechanisms of miRNAs and IncRNAs. miRNAs can bind to target genes to regulate gene expression. IncRNAs play regulation roles in different ways, such as transcriptional and post-transcriptional regulation, chromatin modification, miRNAs sponge, and binding to proteins. 
TABLE 1 | miRNAs as biomarkers in HF.

\begin{tabular}{|c|c|c|c|c|c|c|}
\hline miRNA ID & $\begin{array}{l}\text { Change in } \\
\text { expression }\end{array}$ & $\begin{array}{l}\text { Sample } \\
\text { matrix }\end{array}$ & $\begin{array}{l}\text { Study } \\
\text { description }\end{array}$ & Control group & Main finding & Reference \\
\hline miR-21-5p & $\uparrow$ & Plasma & $\mathrm{HF}(\mathrm{n}=62)$ & Healthy control & By RefFinder and PCR analysis, the six miRNAs were all & (Ding et al., 2020) \\
\hline miR-30a-3p & $\uparrow$ & & & $(n=62)$ & upregulated compared with miR-39 as a reference. The ROC & \\
\hline miR-30a-5p & $\uparrow$ & & & & analysis by MedCalc showed that all AUC values are greater than & \\
\hline miR-155-5p & $\uparrow$ & & & & 0.5 , demonstrating that the detection method was effective. & \\
\hline miR-216a & $\uparrow$ & & & & Correlation analysis indicated that the six miRNAs could be & \\
\hline $\mathrm{miR}-217$ & $\uparrow$ & & & & $\begin{array}{l}\text { combined in two or three or more combinations to become a new } \\
\text { biomarker for HF. }\end{array}$ & \\
\hline $\operatorname{miR}-150-5 p$ & $\downarrow$ & Blood & UVH (n=48) & $\begin{array}{l}\text { Healthy control } \\
(n=32)\end{array}$ & $\begin{array}{l}\text { With the help of UVH, miR-150-5p was the one of three most } \\
\text { significant predictors of overt HF by ROC analysis (AUC 0.905, } \\
95 \% \mathrm{Cl} 0.779-1.000 ; p=0.001 \text { ). }\end{array}$ & $\begin{array}{l}\text { (Abu-Halima et al., } \\
\text { 2019) }\end{array}$ \\
\hline $\operatorname{miR}-423-5 p$ & $\uparrow$ & Plasma & $\begin{array}{l}\text { HF }(n=12) \\
\text { HF }(n=30) \\
\text { Non-HF } \\
\text { Dyspnea }(n=20)\end{array}$ & $\begin{array}{l}\text { Healthy control } \\
(\mathrm{n}=12) \\
\text { Healthy control } \\
(\mathrm{n}=39)\end{array}$ & $\begin{array}{l}\text { A miRNA array and following real-time PCR were performed in two } \\
\text { groups. It was specifically enriched in } \mathrm{HF} \text { and } \mathrm{AUC}=0.91(P<0.01) \text {. } \\
\text { The ROC curve analysis showed miR- } 425-5 p \text { to be a diagnostic } \\
\text { predictor of HF. }\end{array}$ & (Tijsen et al., 2010) \\
\hline $\operatorname{miR}-129-5 p$ & $\downarrow$ & Plasma & $\begin{array}{l}\text { UVH and HF } \\
(\mathrm{n}=71)\end{array}$ & NA & $\begin{array}{l}\text { miR-129-5p is a sensitive and specific biomarker for heart failure in } \\
\text { UVH disease independent of ventricular morphology or stage of } \\
\text { palliation. }\end{array}$ & $\begin{array}{l}\text { (Ramachandran } \\
\text { et al., 2017) }\end{array}$ \\
\hline miR-22 & $\uparrow$ & Serum & Stable chronic & Healthy control & The four miRNAs in HF group were $>1.2$-fold higher than those in & (Goren et al., 2012) \\
\hline miR-92b & $\uparrow$ & & systolic HF & $(n=30)$ & controls, and all AUC > 0.76 & \\
\hline miR-320a & $\uparrow$ & & $(n=30)$ & & The panel of four miRNAs indicate HF with a sensitivity and & \\
\hline $\operatorname{miR}-423-5 p$ & $\uparrow$ & & & & $\begin{array}{l}\text { specificity of } 90 \% \text { and have a significant association with clinical } \\
\text { prognostic parameters such as serum natriuretic peptide levels, a } \\
\text { wide QRS et al. }\end{array}$ & \\
\hline $\operatorname{miR}-21$ & $\uparrow$ & Serum & $\begin{array}{l}\text { HF, LVEF }<50 \% \\
\text { history of } H F>6 \\
\text { months }(n=80)\end{array}$ & $\begin{array}{l}\text { LVEF } \geq 50 \% \text {, no } \\
\text { symptoms } \\
(n=40)\end{array}$ & $\begin{array}{l}\text { Both miR-21-CS and -PV have high levels of sensitivity and } \\
\text { specificity for diagnosing HF. Both have correlation with prognosis, } \\
\text { and miR-21-CS is efficient in predicting re-hospitalization for HF. }\end{array}$ & (Zhang et al., 2017) \\
\hline
\end{tabular}

ROC, Receiver operating characteristic; AUC, Area under curve; UVH, uni-ventricular heart; Cl, Confidence interval; LVEF, Left ventricular ejection fraction; CS, Coronary sinus; PV, Peripheral vein; $\uparrow$ : increase, $\downarrow$ : decrease.

TABLE 2 | IncRNAs as biomarkers in HF

\begin{tabular}{|c|c|c|c|c|c|c|}
\hline $\begin{array}{l}\text { IncRNA } \\
\text { ID }\end{array}$ & $\begin{array}{l}\text { Change in } \\
\text { expression }\end{array}$ & $\begin{array}{l}\text { Sample } \\
\text { matrix }\end{array}$ & $\begin{array}{l}\text { Study } \\
\text { description }\end{array}$ & Control group & Main finding & Reference \\
\hline PVT1 & $\uparrow$ & Serum & $\begin{array}{l}\mathrm{CHF} \\
(\mathrm{n}=92)\end{array}$ & $\begin{array}{l}\text { Healthy control } \\
(\mathrm{n}=60)\end{array}$ & $\begin{array}{l}\text { PVT1 was upregulated, and its target, miR-190a-5p, was downregulated in } \\
\text { CHF patients. Although the both could become independent diagnostic } \\
\text { biomarkers of CHF, the combination of PVT1 and miR-150a-5p showed } \\
\text { better diagnostic accuracy. }\end{array}$ & $\begin{array}{l}\text { (Sun B. et al., } \\
\text { 2020) }\end{array}$ \\
\hline LIPCAR & $\downarrow \rightarrow \uparrow$ & Plasma & $\begin{array}{l}\text { Ischemic HF } \\
(\mathrm{n}=164)\end{array}$ & $\begin{array}{l}\text { Nonischemic HF } \\
(\mathrm{n}=180)\end{array}$ & $\begin{array}{l}\text { The expression of LIPCAR: early after MI } \downarrow \text {, later after } \mathrm{MI} \uparrow, \mathrm{CHF} \uparrow \uparrow . \text { The level } \\
\text { of LIPCR improved the prediction of cardiovascular death, including HF. }\end{array}$ & $\begin{array}{l}\text { (Kumarswamy } \\
\text { et al., 2014) }\end{array}$ \\
\hline $\mathrm{H} 19$ & $\uparrow$ & Plasma & $\begin{array}{l}\text { CAD } \\
(n=300)\end{array}$ & $\begin{array}{l}\text { Healthy control } \\
(n=180)\end{array}$ & $\begin{array}{l}\text { The level of } \mathrm{H} 19 \text { was increased in } \mathrm{CAD} \text { patients with } \mathrm{HF} \text {, and } \mathrm{AUC}=0.63 \text {. } \\
\text { Multivariate logistic regression analyses indicate that } \mathrm{H} 19 \text { was independent } \\
\text { predictor for CAD. }\end{array}$ & $\begin{array}{l}\text { (Gomez et al., } \\
\text { 2018) }\end{array}$ \\
\hline $\mathrm{NRON}$ & $\uparrow$ & Plasma & $\mathrm{HF}(\mathrm{n}=72)$ & Non-HF control & The area under the ROC curve was 0.865 for NRON and 0.702 for MHRT. & (Xuan et al., 2017 \\
\hline MHRT & $\uparrow$ & & & $(n=60)$ & $\begin{array}{l}\text { NRON was negatively correlated with HDL and positively correlated with } \\
\mathrm{LDH} \text {; MHRT was positively correlated with AST and LDH. }\end{array}$ & \\
\hline ANRIL & $\uparrow$ & LV heart & $\mathrm{HF}(\mathrm{n}=54)$ & Healthy control & RT-qPCR was used to detect the expression of IncRNA in LV heart tissue & (Greco et al., 20 \\
\hline HOTAIR & $\downarrow$ & tissue/ & & $(n=52)$ & and PBMCs from non-end-stage, end-stage HF patients, and healthy & \\
\hline TUSC7 & $\downarrow$ & PBMCs & & & $\begin{array}{l}\text { individuals; the expression changes were similar in the two samples, } \\
\text { suggesting a potential as disease biomarker. }\end{array}$ & \\
\hline UCA1 & $\uparrow$ & Plasma & $\begin{array}{l}\mathrm{CHF} \\
(n=64)\end{array}$ & $\begin{array}{l}\text { Healthy control } \\
(n=64)\end{array}$ & $\begin{array}{l}\text { CHF patients with higher UCA1 levels had a lower survival rate compared } \\
\text { with those with a lower level. UCA1 diagnosed CHF with a diagnostic power } \\
\text { of } 0.89 \text { and a sensitivity and specificity of } 100 \% \text { and } 76.12 \%(P<0.05) \text {. }\end{array}$ & (Yu et al., 2017) \\
\hline
\end{tabular}

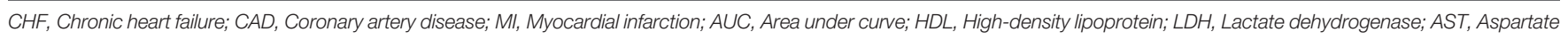
aminotransferase; LV, Left ventricular; PBMCs, Peripheral blood mononuclear cells; $\uparrow:$ increase, $\downarrow$ : decrease, $\rightarrow$ : change.

found that adrenaline could induce the expression of circ-HPIK3 via transcription factor cAMP responsive element-binding protein 1 (CREB1). Circ-HPIK3 would impair the function of heart via increasing $\mathrm{Ca}^{2+}$ concentration by the circ-HPIK3-miR-17-3pAdcy 6 axis in the long run and might be a therapeutic target of HF.
CircRNAs involved in HF have been widely discussed because cardiac hypertrophy contributes to HF. Heart-related circRNAs (circRNAs HRCR) are reported to attenuate cardiac hypertrophy by targeting miR-223. The expression of circRNA HRCR is reduced in thoracic aortic constriction (TAC) and isoproterenol- 

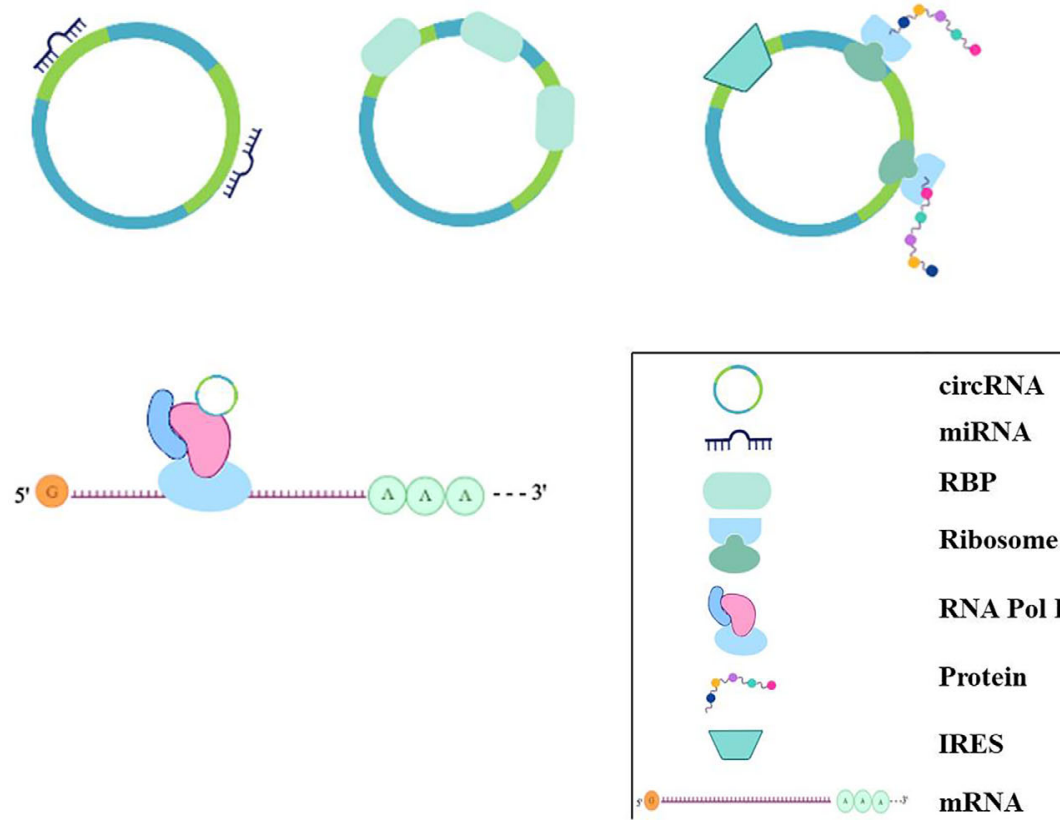

FIGURE 3 | The regulation mechanisms of circRNAs. circRNAs can bind to miRNAs acting as miRNA sponges; some circRNAs can bind to protein, especially RBP, acting as sponge or decoy; some can regulate transcriptionally through interacting with RNA Pol II, or some circRNAs even have the potential role of coding for proteins by internal ribosome entry site.

TABLE 3 | circRNAs as regulatory noncoding RNAs in HF.

\begin{tabular}{|c|c|c|c|c|c|c|}
\hline circRNA ID & $\begin{array}{l}\text { Change in } \\
\text { expression }\end{array}$ & $\begin{array}{l}\text { Disease } \\
\text { model }\end{array}$ & $\begin{array}{l}\text { Model/ } \\
\text { species }\end{array}$ & $\begin{array}{l}\text { Implication in } \\
\text { HF }\end{array}$ & Main finding & Reference \\
\hline circSlc8a1 & $\uparrow$ & Hypertrophy & mouse & $\begin{array}{l}\text { Upregulation } \\
\text { aggravates HF }\end{array}$ & $\begin{array}{l}\text { CircSlc8a1 induced HF via regulating the expression of Srf, CTGF, } \\
\beta 1-A R \text { via sponging miR-133a or Adcy6 directly. }\end{array}$ & (Lim et al., 2019) \\
\hline $\mathrm{HRCR}$ & $\downarrow$ & Hypertrophy & mouse & $\begin{array}{l}\text { Upregulation } \\
\text { alleviates } \\
\text { hypertrophy }\end{array}$ & HRCR attenuated cardiac hypertrophy by targeting miR-223. & (Wang et al., 2016) \\
\hline circRNA_000203 & $\uparrow$ & Hypertrophy & mouse & $\begin{array}{l}\text { Upregulation } \\
\text { aggravates } \\
\text { hypertrophy }\end{array}$ & $\begin{array}{l}\text { CircRNA_000203 could sponge miR-26b-5p and miR-140-3p, } \\
\text { abolish their synergistic inhibition of Gata4, resulting in aggravating } \\
\text { hypertrophy. }\end{array}$ & (Li et al., 2020) \\
\hline circ-HPIK3 & $\uparrow$ & Ml & mouse & $\begin{array}{l}\text { Upregulation } \\
\text { aggravates } \mathrm{Ml}\end{array}$ & $\begin{array}{l}\text { The expression of circ-HPIK3 was regulated by adrenaline via } \\
\text { CREB1, circ-HPIK3-miR-17-3p- Adcy6 axis played roles in regulating } \\
\text { heart function. }\end{array}$ & (Deng et al., 2019) \\
\hline circNfix & $\uparrow$ & Ml & $\begin{array}{l}\text { mouse } \\
\text { rat }\end{array}$ & $\begin{array}{l}\text { Downregulation } \\
\text { alleviates } \mathrm{Ml}\end{array}$ & $\begin{array}{l}\text { The expression of circNfix was regulated by Meis1, and circNfix } \\
\text { reinforced the interaction of YBX1 and NEDD4L to decrease YBX1, } \\
\text { and regulated Gsk3 } 3 \text { signaling by miR-214. }\end{array}$ & $\begin{array}{l}\text { (Huang et al., } \\
\text { 2019) }\end{array}$ \\
\hline ACAP2 & $\uparrow$ & Ml & rat & $\begin{array}{l}\text { Upregulation } \\
\text { aggravates } \mathrm{Ml}\end{array}$ & $\begin{array}{l}\text { CircRNA ACAP2 had better stability and resistance to RNase } R \text {. } \\
\text { ACAP2 promoted the apoptosis of cardiomyocytes through binding } \\
\text { to miR-29. }\end{array}$ & (Liu et al., 2020) \\
\hline circRNA 010567 & $\uparrow$ & Ml & rat & $\begin{array}{l}\text { Upregulation } \\
\text { aggravates } \mathrm{Ml}\end{array}$ & $\begin{array}{l}\text { Decreased the expression of circRNA } 010567 \text { could improve the } \\
\text { cardiac function, alleviated the myocardial fibrosis by inhibiting TGF- } \\
\beta 1 \text { signaling pathway. }\end{array}$ & (Bai et al., 2020) \\
\hline circ_LAS1L & $\downarrow$ & Ml & human & $\begin{array}{l}\text { Upregulation } \\
\text { alleviates } \mathrm{Ml}\end{array}$ & $\begin{array}{l}30 \text { AMl patients and } 30 \text { healthy volunteers were enrolled in this study. } \\
\text { Circ_LAS1L inhibited cardiac fibroblasts proliferation by sponging } \\
\text { miR-125b to increase the expression of SFRP5. }\end{array}$ & $\begin{array}{l}\text { (Sun L. Y. et al., } \\
\text { 2020) }\end{array}$ \\
\hline
\end{tabular}

Sif, Serum response factor; CTGF, Connective tissue growth factor; $\beta 1$-AR, $\beta 1$-adrenergic receptor; Adcy6, Adenylate cyclase 6; Gata4, Gata binding protein 4; CREB1, cAMP responsive element-binding protein 1; YBX1, Y-box bingding protein 1; NEDD4L, an E3 ubiquitin ligase; APP, Amyloid $\beta$ precursor protein; FUS, FUS RNA binding protein, VEGF-A, Vascular endothelial growth factor-A; SFRP5, Secreted frizzled-related protein 5; $\uparrow$ : increase, $\downarrow$ : decrease. 
induced cardiac hypertrophy mouse models (Wang et al., 2016). The expression of circRNA_000203 was increasing in in vitro and in vivo models of cardiac hypertrophy (Li et al., 2020). Overexpression of circRNA_000203 both in vitro by transfection recombinant adenovirus into neonatal mouse ventricular cardiomyocytes (NMVCs) and in vivo transgenically would induce a hypertrophy phenotype. CircRNA_000203 could sponge miR-26b-5p and miR-140-3p and abolish the synergistic inhibition of Gata4, a pro-hypertrophy factor. Furthermore, NF- $\kappa \mathrm{B}$ signaling also took part in cardiac hypertrophy regulated by circRNA_000203.

In addition, ischemic-induced cardiac remodeling is also an important promoter of HF. Myocardial infarction (MI) is an ischemic cardiomyopathy caused by insufficient coronary blood supply and induces necrosis and apoptosis of cardiomyocytes. The remaining cardiomyocytes cannot achieve self-repair and are forced to undergo compensatory hypertrophy. At the same time, the proliferation of fibroblasts is activated, resulting in ventricular remodeling and myocardial fibrosis. A long-term cardiac workload will eventually lead to HF (Pouleur et al., 2010). It is reported that the transcription factor Meis1 has a regulatory effect on the regeneration of cardiomyocytes. A recent study showed that Meis1 bounded to the super-enhancer at the circNfix locus and increased its expression (Huang et al., 2019). However, loss of super-enhancer-regulated circNfix could promote cardiac regeneration after MI. This study may indicate that circNfix may be a key regulator for improving the prognosis after MI and inhibiting the progression of HF. This also further explains the proliferation ability of adult mice being reactivated after Meis1 knockout (Mahmoud et al., 2013). CDYL is another circRNA reported to modulate cardiac regeneration after acute MI (Zhang M. et al., 2020). Overexpression of circRNA CDYL could promote proliferation of cardiomyocytes in vitro through sponging miR-4793-5p. These circRNAs attenuate the development of $\mathrm{HF}$ by regulating the proliferation of cardiomyocytes after MI.

CircRNA circFndc3b was significantly downregulated in postMI hearts and also decreased in cardiac tissues of ischemic cardiomyopathy patients. AAV-9-mediated overexpression of circFndc $3 \mathrm{~b}$ reduced cardiomyocyte apoptosis and improved angiogenesis and contractile function in a rat model of MI via interaction with RNA binding protein FUS (Garikipati et al., 2019). Similarly, circRNA ACAP2 exacerbated the development of HF via promoting the apoptosis of cardiomyocytes by targeting to miR-29 (Liu et al., 2020). The two circRNAs modulate the progression of HF by regulating the cardiomyocyte apoptosis after MI.

In addition, preventing ventricular remodeling is an effective way to inhibit HF. MI-induced myocardial fibrosis (MF) is an important mechanism to induce ventricular remodeling. Silencing circRNA 010567 in the rat model of acute MI established that using ligation of the left anterior descending coronary artery would improve cardiac function, higher ejection fraction, and fractional shortening and alleviate MF through the TGF- $\beta 1$ signaling pathway (Bai et al., 2020). A cardioprotective circRNA, circ_LAS1L, was found markedly downregulated in acute MI (Sun L. Y. et al., 2020). Overexpression of circ_LAS1L could inhibit cardiac fibroblast proliferation and migration and promote apoptosis. Mechanistically, circ_LAS1L sponged miR$125 \mathrm{~b}$ to upregulate the expression of secreted frizzled-related protein 5 (SFRP5) and inhibit the expression of $\alpha$-SMA, collagen $\mathrm{I}$, and collagen III to play an important role in the process of MF.

These findings demonstrate that circRNAs have potential regulatory functions in $\mathrm{HF}$ and inhibit symptoms that can induce HF, including hypertrophy, cardiomyocyte apoptosis, and ventricular remodeling. Interestingly, circRNAs have been detected in the bloodstream (Vausort et al., 2016), signifying the possibility of constituting a reservoir of novel biomarkers. In addition, due to their putative ability to aid in the advancement of personalized health care of patients with HF and their presence in circulation, circRNAs can be used as potential diagnostic tools.

\section{CIRCRNAS AS BIOMARKERS OF HF}

Similar to miRNAs and lncRNAs, circRNAs also have the potential of being used as biomarkers of HF and can even be more effective than miRNAs and lncRNAs. First, circRNAs have excellent stability associated with their circularized structure, which protects them from endonuclease activities (Memczak et al., 2015). Therefore, the half-life of circRNAs in cells is longer than that of other IncRNAs that are released by extracellular vesicles (Alhasan et al., 2016). Second, circRNAs are widely distributed and can be detected in blood, plasma, and extracellular vesicles (Koh et al., 2014; Vausort et al., 2016). Third, circRNAs are present in large amounts in the blood (Memczak et al., 2015), exceeding the corresponding linear mRNAs by more than 10-fold (Jeck et al., 2013). Fourth, RNAsequencing technology has identified hundreds of cell-specific circRNAs in human and mouse cells and tissues, providing more candidates for the selection of disease biomarkers (Salzman et al., 2013). CircRNAs have been described as potential biomarkers for atherosclerotic cardiovascular disease risk, depressive disorder, aging, and cancer despite inadequate evidence of their functions in HF (Burd et al., 2010; Westholm et al., 2014; Bahn et al., 2015; Li et al., 2015; Chen et al., 2017). Therefore, there is evidence that circRNAs are potential biomarkers for HF.

There is increasing evidence indicating that the expression of specific circRNAs is dysregulated in cardiovascular disease. For example, hsa_circ_01224644 has been reported as a potential biomarker of coronary artery disease due to its upregulation during the progression of the disease (Zhao et al., 2017). In addition, the circRNA has_circ_0001445 has been reported to enhance the identification of atherosclerotic coronary artery disease (Vilades et al., 2020). RNA sequencing analysis was performed on human failing hearts and TAC mice in a previous study (Werfel et al., 2016). The study detected three circRNAs that were significantly altered; expressions of m005501 and m005492 were upregulated, whereas m005505 expression was downregulated. People have put forth that two independent studies have shown that two circRNAs were identified as 
differentially expressed when comparing young and aged hearts (Du et al., 2017; Zeng et al., 2017). Circ-FOXO3 was significantly expressed in aged human and mouse hearts, and circ-Amotl1 was highly expressed in neonatal human heart tissue. Whether these two circRNAs can be put together to indicate the degree of HF is worthy of our study. Consequently, circRNAs are appropriate for the diagnosis of cardiovascular diseases and are potential biomarkers of HF. The changes of circRNAs as biomarkers of HF are summarized in Table 4.

A previous study demonstrated that the expression of circRNA referred to as MI-associated circular RNA (MICRA) is reduced in patients with acute MI compared with healthy people and may act as a predictor of the risk of left ventricular dysfunction after acute MI. MICRA is also downregulated in patients with decreased ejection fraction, suggesting its potential role as a HF biomarker (Vausort et al., 2016). Recently, a patent file (Google patent: WO2017046203A1) demonstrated that the expression of MICRA, circ_0000005, circ_0000673, circ_0000585, circ_0000816, circ_0000817, circ_0000917, circ_0001423, circ_0000540, circ_0001844, circ_0000994, and circNPPA is out of tune in HF. A total of 496 people were enrolled in this trial, including healthy volunteers $(n=86)$, STelevation MI $(n=270)$, and non-ST-elevation MI $(n=139)$. The expression of MICRA in healthy volunteers and MI patients are significantly different, but there were none in ST-elevation or non-ST-elevation MI. In this trial, the expression levels of MICRA were measured by quantitative PCR. Beyond this, left ventricular function, ejection fraction and demographic and

TABLE 4 | circRNAs as biomarkers in HF.

\begin{tabular}{|c|c|c|c|c|c|c|}
\hline circRNA ID & $\begin{array}{l}\text { Change in } \\
\text { expression }\end{array}$ & $\begin{array}{l}\text { Sample } \\
\text { matrix }\end{array}$ & $\begin{array}{l}\text { Study descrip- } \\
\text { tion }\end{array}$ & Control group & Main finding & Reference \\
\hline m005501 & $\uparrow$ & Heart & Adult rat $(n=3)$ & Neonatal rat $(n=3)$ & RNA sequencing analysis was performed on heart tissue of & (Werfel et al., \\
\hline m005492 & $\uparrow$ & tissue & TAC mice $(n=2)$ & Sham mice $(n=3)$ & HF model, including human, rat, and mouse. These three & 2016) \\
\hline m005505 & $\downarrow$ & & HF patient $(n=2)$ & $\begin{array}{l}\text { Non-failing heart } \\
(\mathrm{n}=2)\end{array}$ & $\begin{array}{l}\text { circRNAs had a significant change in expression, indicating } \\
\text { they might have a directive function of HF. }\end{array}$ & \\
\hline circ-FOXO3 & $\uparrow$ & $\begin{array}{l}\text { Heart } \\
\text { tissue } \\
\text { CMs }\end{array}$ & $\begin{array}{l}\text { Human }>50 \\
\text { years }(n=11) \\
\text { CMs isolated } \\
\text { from neonatal } \\
\text { mice }\end{array}$ & $\begin{array}{l}\text { Human }<50 \text { years } \\
(\mathrm{n}=9) \\
\text { CMs isolated from } \\
12 \text { week mice }\end{array}$ & $\begin{array}{l}\text { The expression of circ-FOXO3 was higher in aged hearts. } \\
\text { Inversely, circ-Amotl1 was highly expressed in neonatal } \\
\text { hearts. These two circRNAs can be put together to indicate } \\
\text { the degree of HF }\end{array}$ & (Du et al., 2017) \\
\hline circ-Amotl1 & $\downarrow$ & $\begin{array}{l}\text { Heart } \\
\text { tissue }\end{array}$ & \multicolumn{2}{|c|}{$\begin{array}{l}\text { The population enrolled in this study } \\
\text { was aged from younger than } 1 \text { years } \\
\text { to } 76 \text { years old }\end{array}$} & & (Zeng et al., 2017) \\
\hline MICRA & $\downarrow$ & Blood & $\begin{array}{l}\text { ST-elevation Ml } \\
(\mathrm{n}=270) \\
\text { non } \\
\text { ST-elevation Ml } \\
(\mathrm{n}=139)\end{array}$ & $\begin{array}{l}\text { healthy volunteers } \\
(\mathrm{n}=86)\end{array}$ & $\begin{array}{l}\text { Evaluating the subjects' expression of MICRA and heart } \\
\text { condition through left ventricular function, ejection fraction, } \\
\text { demographic, and clinical variables, circRNA MICRA could } \\
\text { be used as a biomarker of HF. In addition, some other } \\
\text { circRNAs were also detected; these circRNAs might play } \\
\text { roles in the diagnosis of HF combined with MICRA. }\end{array}$ & (Yvan et al., 2017) \\
\hline CFNDC3B & $\uparrow$ & LV & $\mathrm{DCM}(\mathrm{n}=26)$ & Control $(n=23)$ & The 6 circRNAs were identified with reproducible & (Yvan and Lu, \\
\hline cBPTF & $\uparrow$ & tissue & $\mathrm{ICM}(\mathrm{n}=17)$ & & associations with HF and had a significant expression & 2018) \\
\hline cEXOC6B & $\uparrow$ & & & & differential and stability, and therefore, key biomarkers for & \\
\hline CLAMA2-2 & $\uparrow$ & & & & the diagnosis of HF and/or predicting the clinical evolution & \\
\hline cPLCEI & $\uparrow$ & & & & of HF in a patient. & \\
\hline cPRDM5 & $\uparrow$ & & & & & \\
\hline hsa_circ_0062960 & $\uparrow$ & Plasma & $\begin{array}{l}\text { Chronic stable } \\
\mathrm{HF}(\mathrm{n}=30)\end{array}$ & Control $(n=30)$ & $\begin{array}{l}\text { The expression of hsa_circ_0062960 was highly correlated } \\
\text { with BNP. GO and KEGG pathway analyses shown the } \\
\text { expression to also be related to platelet activity. }\end{array}$ & $\begin{array}{l}\text { (Sun Y. et al., } \\
\text { 2020) }\end{array}$ \\
\hline DNAJC6, & $\downarrow$ & Serum & HNCM $(n=33)$ & Control $(n=53)$ & CircRNAs TMEM56 and DNAJC6 were negatively correlated & (Sonnenschein \\
\hline TMEM56 & $\downarrow$ & & $\operatorname{HOCM}(n=31)$ & & with echocardiographic parameters for $\mathrm{HOCM}$ and could be & et al., 2019) \\
\hline MBOAT2 & $\downarrow$ & & & & $\begin{array}{l}\text { used as indicators of disease severity in patients with } \\
\text { HOCM. }\end{array}$ & \\
\hline hsa_circ_0001445 & $\downarrow$ & Plasma & Stable CAD $(n=2 C$ & & $\begin{array}{l}\text { The stability of hsa_circ_0001445 was detected in room } \\
\text { temperature, } 4^{\circ} \mathrm{C} \text {, freeze/thaw cycles and hemolysis. It will } \\
\text { also improve the accuracy of diagnose CAD. }\end{array}$ & $\begin{array}{l}\text { Vilades et al., } \\
\text { 2020) }\end{array}$ \\
\hline has_circ_0005540 & $\uparrow$ & Plasma & CAD $(n=108)$ & Non-CAD $(n=89)$ & $\begin{array}{l}\text { An exoRNwasy Serum/Plasma Midi kit was used to isolate } \\
\text { total exosome RNA from plasma. Has_circ_0005540 was } \\
\text { selected from } 355 \text { circRNAs, which had a remarkably fold } \\
\text { change and associated with CAD. }\end{array}$ & (Wu et al., 2020) \\
\hline has_circ_0097435 & $\uparrow$ & Plasma & $\mathrm{HF}(\mathrm{n}=45)$ & $\begin{array}{l}\text { Healthy volunteer } \\
(\mathrm{n}=44)\end{array}$ & $\begin{array}{l}\text { The expression of exosmal has_circ_0097435 was } \\
\text { increased in HF patients. In vivo, overexpression of } \\
\text { has_circ_0097435 could induce cardiomyocyte apoptosis, } \\
\text { and silencing has_circ_0097435 inhibited apoptosis. It will } \\
\text { also play roles in HF by sponging multiple miRNAs. }\end{array}$ & (Han et al., 2020) \\
\hline
\end{tabular}

CMs, Cardiomyocytes; DCM, Dilated cardiomyopathy; ICM, Ischemic cardiomyopathy; GO, Gene Ontology; KEGG, Kyoto Encyclopedia of Genes and Genomes; HNCM, Non-obstructive hypertrophic cardiomyopathy; HOCM, Obstructive hypertrophic cardiomyopathy; CAD, Coronary artery disease; $\uparrow:$ increase, $\downarrow$ : decrease. 
clinical variables were assessed at a 4-month follow-up to evaluate the subjects' heart condition. Furthermore, the patient also maintained the use of the listed circRNAs in the diagnosis of $\mathrm{HF}$, indicating that circRNA MICRAs can be used as biomarkers for HF (Bayoumi et al., 2018). In addition, this team also identified novel HF-associated circRNAs as biomarkers for HF (Google patent: WO2018220185A1). These circRNAs, including cFNDC3B, cBPTF, cEXOC6B, cLAMA2-2, cPLCEI, and cPRDM5 were differentially expressed between subjects with failing hearts and subjects with nonfailing hearts. Therefore, these novel circRNAs most likely have a function in HF and further can be used as biomarkers for diagnosis of HF for the prediction of the clinical evolution of HF, such as the prediction of the development of cardiac decompensation. Similarly, in another study, hsa_circ_0062960 exhibited a higher expression in patients with HF, and the area under the curve (AUC) for HF diagnosis was $0.838(p<0.0001)$. Notably, correlation analysis shows that the expression of hsa_circ_0062960 is highly positively correlated with the serum level of BNP, signifying its potential role as a biomarker of HF (Sun Y. et al., 2020).

There were three circRNAs identified as potential biomarkers for the hypertrophic cardiomyopathy (HCM) (Sonnenschein et al., 2019). Serum expression levels of the three circRNAs, DNAJC6, TMEM56, and MBOAT2, were identified in blood samples from 64 patients with HCM and 53 healthy controls and were both downregulated. Abundance of circRNAs was correlated to relevant clinical parameters, and the result showed that the three circRNAs could distinguish between healthy and HCM patients. In addition, TMEM56 and DNAJC6 could also serve as indicators of disease severity in patients with HCM. Of note, circRNA hsa_circ_0001445 exhibited remarkable stability tested under different experimental conditions in samples from 5 healthy blood donor volunteers (Vilades et al., 2020). In a real-world clinical practice setting containing 200 consecutive patients with suspected stable coronary artery disease (CAD), the classification of patients was much more accurate with the incorporation of has_circ_0001445 into a base clinical model composed of conventional cardiovascular risk factors, thus supporting its role as a biomarker of CAD.

Circulating noncoding RNAs occur in serum in 2 forms: free nucleic acids and nucleic acids contained in exosomes. Noncoding RNAs isolated from exosomes are tested at higher sensitivities than those in the serum (Gallo et al., 2012). Exosomes are extracellular vesicles (EVs) derived from multivesicular bodies (MVBs) and are distinguished from microvesicles (MVs) and apoptotic bodies by size and biogenesis (Maas et al., 2017). Exosomes can function as biomarkers of HF predominantly through their noncoding RNA cargos (Yuan et al., 2018). Exosomes encapsulate noncoding RNAs and then secrete them into peripheral blood, thus protecting them from enzymatic degradation. Cardiac ischemia/reperfusion (I/R) could increase the secretion of EVs; the following RNA-seq of EVs identified 185 significantly differentially expressed circRNAs, 119 downregulated and 66 upregulated, compared with the sham, suggesting that circRNAs in cardiac EVs might indicate development of I/R as biomarkers (Ge et al., 2019). Using circRNAs to improve the discriminatory power for CVD has been discussed (Wu et al., 2020). Exosmal circRNA expression levels in exosomes was analyzed from 3 plasma samples of CAD patients and 3 paired controls using RNA sequencing. CircRNA has_circ_0005540 was selected as a candidate biomarker for CVD from 164 upregulated circRNAs and 191 downregulated circRNAs because it had a significant differential expression (fold change $>4, P<0.05$ ) and associated with CVD $(P<0.0001)$. Has_circ_0005540 also showed a high discriminatory power for CVD in ROC analyses (AUC $=0.853$, 95\% CI=0.799-0.906, $P<0.001)$. These results suggest that plasma exosomal has_circ_0005540 could be used as a promising biomarker of CVD. Exosomes extracted from peripheral blood samples of patients with $\mathrm{HF}$ and healthy patients (control group) were analyzed using next-generation sequencing, and the results indicate that the expression of has_circ_0097435 was upregulated in patients with HF. The high expression of hsa_circ_0097435 in exosomes demonstrates that most hsa_circ_0097435 are encapsulated in the exosomes, confirming that hsa_circ_0097435 is a potential biomarker of HF (Han et al., 2020).

\section{LIMITATIONS}

That circRNAs can become HF biomarkers is not random. For example, a recent study examining 953 patients with chronic and symptomatic HF revealed a positive correlation between miR132 expression levels and the critical state of $\mathrm{HF}$ and $\mathrm{HF}$ hospitalizations (Masson et al., 2018). In patients with acute decompensated HF, the reduced levels of ncRNAs are attributed to fluid overload. This also attracts an interesting opinion that tracing the origin of circulating ncRNAs in HF is important. CircRNAs act as attractive therapeutic targets and biomarkers for $\mathrm{HF}$ because of their peculiarity. The identification of circRNA profiles in HF may result in new diagnostic tools. CircRNAs may also have an added advantage over other existing methods and biomarkers by providing additional information to guide clinical decisions. Therefore, there is convincing evidence on the potential of circRNAs as biomarkers of $\mathrm{HF}$ in clinical applications. However additional research should be conducted to resolve the hurdles and promote the application of circRNAs as biomarkers for HF. The use of circRNAs as biomarkers for HF is partially limited by both technical and nontechnical barriers.

Accuracy is a crucial determinant in the use of circRNAs as biomarkers of HF. Studies have demonstrated that a certain miRNA was downregulated in patients with acute HF but not in chronic HF patients (Ovchinnikova et al., 2016). This implies that the noncoding RNA biomarkers should be used in hierarchical prediction to ensure accuracy and effectiveness. Confounding factors, such as age, sex, cardiovascular risk factors, and pharmacological treatments, among others, should also be considered in the prediction results (De Gonzalo-Calvo et al., 2019). In addition, the use of clusters of circRNAs rather than single circRNAs may improve accuracy. 
Comparing and reproducing results from different studies, including study designs, materials, sample isolation, techniques, normalization strategies, and the influence of drugs and disease is challenging (Backes et al., 2015; Gomes et al., 2020). For example, most current studies do not have unified normalization strategies, and both endogenous and exogenous references vary. Isolation, purification, and characterization of exosomal circRNA biomarkers from MVBs, lipoproteins, and macromolecular complexes is still a major challenge despite the application of different techniques, including chromatography, centrifugation, precipitation, and affinity-isolation (Lawson et al., 2016; Takov et al., 2019). Fortunately, some studies on circRNA detection have already begun (Google patent: CN111378741A). Specfically, a molecular label containing a fluorescent reporter group and a quencher group were coupled on a nucleic acid probe targeting a circRNA. When the blood contained the circRNA to be detected, the circRNA was subjected to base complementary pairing, and the reaction liquid in the 5' to 3' exonuclease appraisal formed double-stranded nucleic acid group in order for the nucleotide sequence between the fluorescent reporter group and the quenching group on the nucleic acid probe to be cut; the fluorescent report group is dissociated from the nucleic acid probe targeting the circRNA into the reaction liquid, and then a fluorescent signal is emitted. Another limitation is that of the light wavelength in flow cytometry, which makes it difficult to distinguish exosomes from other EVs (Lawson et al., 2016). The use of fingerprint proteins, such as tetraspanins CD9, CD63, CD81, and CD82, may be a more effective method of isolating exosomes. However, this method can only distinguish exosomes from other EVs, and it is not possible to retrospectively determine which kind of cells derived them (Arraud et al., 2014; Kowal et al., 2016). Therefore, reliable methods and standardization strategies are required to enhance the translation of basic research into clinical practice. The present findings on the use of circRNAs as biomarkers of HF are very promising although

\section{REFERENCES}

Abu-Halima, M., Meese, E., Saleh, M. A., Keller, A., Abdul-Khaliq, H., and RaedleHurst, T. (2019). Micro-RNA 150-5p predicts overt heart failure in patients with univentricular hearts. PloS One 14, e0223606. doi: 10.1371/ journal.pone.0223606

Alhasan, A. A., Izuogu, O. G., Al-Balool, H. H., Steyn, J. S., Evans, A., Colzani, M., et al. (2016). Circular RNA enrichment in platelets is a signature of transcriptome degradation. Blood 127, e1-e11. doi: 10.1182/blood-2015-06649434

Arraud, N., Linares, R., Tan, S., Gounou, C., Pasquet, J. M., Mornet, S., et al. (2014). Extracellular vesicles from blood plasma: determination of their morphology, size, phenotype and concentration. J. Thromb. Haemost. 12, 614-627. doi: 10.1111/jth.12554

Ashwal-Fluss, R., Meyer, M., Pamudurti, N. R., Ivanov, A., Bartok, O., Hanan, M., et al. (2014). circRNA biogenesis competes with pre-mRNA splicing. Mol. Cell 56, 55-66. doi: 10.1016/j.molcel.2014.08.019

Backes, C., Leidinger, P., Altmann, G., Wuerstle, M., Meder, B., Galata, V., et al. (2015). Influence of next-generation sequencing and storage conditions on miRNA patterns generated from PAXgene blood. Anal. Chem. 87, 8910-8916. doi: 10.1021/acs.analchem.5b02043

Backs, J., Song, K., Bezprozvannaya, S., Chang, S., and Olson, E. N. (2006). CaM kinase II selectively signals to histone deacetylase 4 during cardiomyocyte hypertrophy. J. Clin. Invest. 116, 1853-1864. doi: 10.1172/JCI27438 further studies should be conducted to resolve the limitations of the currently used diagnostic markers.

\section{CONCLUSION AND FUTURE PROSPECTS}

The development of novel biomarkers for HF is of great significance considering the risks of $\mathrm{HF}$ and the limitations of existing diagnostic markers for HF. This article discusses the potential use of circRNAs as HF biomarkers. Despite the differences present in circRNAs examined in animal models or HF patients' samples, assessment techniques that may influence their accuracy and the need for further research, the present findings strongly indicate that circRNAs can be used as effective predictive and diagnostic biomarkers of HF.

\section{AUTHOR CONTRIBUTIONS}

$\mathrm{CS}, \mathrm{MN}$, and BS wrote the manuscript. LC provided direction and edited the manuscript. All authors contributed to the article and approved the submitted version.

\section{FUNDING}

This work was supported by grants from the Nanjing Medical University Science and Technology Development Foundation (2017NJMU059).

\section{ACKNOWLEDGMENTS}

Thanks for the help from Dr. Yuan Jiang; she gave many comments on the revision of the review.

Bahn, J. H., Zhang, Q., Li, F., Chan, T. M., Lin, X., Kim, Y., et al. (2015). The landscape of microRNA, Piwi-interacting RNA, and circular RNA in human saliva. Clin. Chem. 61, 221-230. doi: 10.1373/clinchem.2014.230433

Bai, M., Pan, C. L., Jiang, G. X., and Zhang, Y. M. (2020). CircRNA 010567 improves myocardial infarction rats through inhibiting TGF-beta1. Eur. Rev. Med. Pharmacol. Sci. 24, 369-375. doi: 10.26355/eurrev_202001_19935

Bayoumi, A. S., Aonuma, T., Teoh, J. P., Tang, Y. L., and Kim, I. M. (2018). Circular noncoding RNAs as potential therapies and circulating biomarkers for cardiovascular diseases. Acta Pharmacol. Sin. 39, 1100-1109. doi: 10.1038/ aps.2017.196

Burd, C. E., Jeck, W. R., Liu, Y., Sanoff, H. K., Wang, Z., and Sharpless, N. E. (2010). Expression of linear and novel circular forms of an INK4/ARFassociated non-coding RNA correlates with atherosclerosis risk. PloS Genet. 6, e1001233. doi: 10.1371/journal.pgen.1001233

Cao, Z., Jia, Y., and Zhu, B. (2019). BNP and NT-proBNP as Diagnostic Biomarkers for Cardiac Dysfunction in Both Clinical and Forensic Medicine. Int. J. Mol. Sci. 20, 1820. doi: 10.3390/ijms20081820

Chen, L. L., and Yang, L. (2015). Regulation of circRNA biogenesis. RNA Biol. 12, 381-388. doi: 10.1080/15476286.2015.1020271

Chen, S., Li, T., Zhao, Q., Xiao, B., and Guo, J. (2017). Using circular RNA hsa_circ_0000190 as a new biomarker in the diagnosis of gastric cancer. Clin. Chim. Acta 466, 167-171. doi: 10.1016/j.cca.2017.01.025

Chen, L. L. (2016). The biogenesis and emerging roles of circular RNAs. Nat. Rev. Mol. Cell Biol. 17, 205-211. doi: 10.1038/nrm.2015.32 
Chu, Q., Li, A., Chen, X., Qin, Y., Sun, X., Li, Y., et al. (2018). Overexpression of miR-135b attenuates pathological cardiac hypertrophy by targeting CACNA1C. Int. J. Cardiol. 269, 235-241. doi: 10.1016/j.ijcard.2018. 07.016

Czubryt, M. P., Mcanally, J., Fishman, G. I., and Olson, E. N. (2003). Regulation of peroxisome proliferator-activated receptor gamma coactivator 1 alpha (PGC-1 alpha ) and mitochondrial function by MEF2 and HDAC5. Proc. Natl. Acad. Sci. U.S.A. 100, 1711-1716. doi: 10.1073/pnas.0337639100

De Gonzalo-Calvo, D., Vea, A., Bar, C., Fiedler, J., Couch, L. S., Brotons, C., et al. (2019). Circulating non-coding RNAs in biomarker-guided cardiovascular therapy: a novel tool for personalized medicine? Eur. Heart J. 40, 1643-1650. doi: 10.1093/eurheartj/ehy234

Deng, Y., Wang, J., Xie, G., Zeng, X., and Li, H. (2019). Circ-HIPK3 Strengthens the Effects of Adrenaline in Heart Failure by MiR-17-3p - ADCY6 Axis. Int. J. Biol. Sci. 15, 2484-2496. doi: 10.7150/ijbs.36149

Di Marca, S., Rando, A., Cataudella, E., Pulvirenti, A., Alaimo, S., Terranova, V., et al. (2018). B-type natriuretic peptide may predict prognosis in older adults admitted with a diagnosis other than heart failure. Nutr. Metab. Cardiovasc. Dis. 28, 636-642. doi: 10.1016/j.numecd.2018.02.017

Ding, H., Wang, Y., Hu, L., Xue, S., Zhang, L., Zhang, Y., et al. (2020). Combined detection of miR-21-5p, miR-30a-3p, miR-30a-5p, miR-155-5p, miR-216a and miR-217 for screening of early heart failure diseases. Biosci. Rep. 40, BSR20191653. doi: 10.1042/BSR20191653

Du, W. W., Yang, W., Chen, Y., Wu, Z. K., Foster, F. S., Yang, Z., et al. (2017). Foxo3 circular RNA promotes cardiac senescence by modulating multiple factors associated with stress and senescence responses. Eur. Heart J. 38, $1402-$ 1412. doi: 10.1093/eurheartj/ehw001

Gaggin, H. K., and Januzzi, J. L.Jr. (2013). Biomarkers and diagnostics in heart failure. Biochim. Biophys. Acta 1832, 2442-2450. doi: 10.1016/j.bbadis. 2012.12.014

Gallo, A., Tandon, M., Alevizos, I., and Illei, G. G. (2012). The majority of microRNAs detectable in serum and saliva is concentrated in exosomes. PloS One 7, e30679. doi: 10.1371/journal.pone.0030679

Garikipati, V. N. S., Verma, S. K., Cheng, Z., Liang, D., Truongcao, M. M., Cimini, M., et al. (2019). Circular RNA CircFndc3b modulates cardiac repair after myocardial infarction via FUS/VEGF-A axis. Nat. Commun. 10, 4317. doi: 10.1038/s41467-019$11777-7$

Ge, X., Meng, Q., Zhuang, R., Yuan, D., Liu, J., Lin, F., et al. (2019). Circular RNA expression alterations in extracellular vesicles isolated from murine heart post ischemia/reperfusion injury. Int. J. Cardiol. 296, 136-140. doi: 10.1016/ j.ijcard.2019.08.024

Gomes, C. P. C., Schroen, B., Kuster, G. M., Robinson, E. L., Ford, K., Squire, I. B., et al. (2020). Regulatory RNAs in Heart Failure. Circulation 141, 313-328. doi: 10.1161/CIRCULATIONAHA.119.042474

Gomez, J., Lorca, R., Reguero, J. R., Martin, M., Moris, C., Alonso, B., et al. (2018). Genetic variation at the long noncoding RNA H19 gene is associated with the risk of hypertrophic cardiomyopathy. Epigenomics 10, 865-873. doi: 10.2217/ epi-2017-0175

Goren, Y., Kushnir, M., Zafrir, B., Tabak, S., Lewis, B. S., and Amir, O. (2012). Serum levels of microRNAs in patients with heart failure. Eur. J. Heart Fail 14, 147-154. doi: 10.1093/eurjhf/hfr155

Greco, S., Zaccagnini, G., Perfetti, A., Fuschi, P., Valaperta, R., Voellenkle, C., et al. (2016). Long noncoding RNA dysregulation in ischemic heart failure. J. Transl. Med. 14, 183. doi: 10.1186/s12967-016-0926-5

Han, J., Zhang, L., Hu, L., Yu, H., Xu, F., Yang, B., et al. (2020). Circular RNAExpression Profiling Reveals a Potential Role of Hsa_circ_0097435 in Heart Failure via Sponging Multiple MicroRNAs. Front. Genet. 11, 212. doi: 10.3389/ fgene.2020.00212

Hansen, T. B., Jensen, T. I., Clausen, B. H., Bramsen, J. B., Finsen, B., Damgaard, C. K., et al. (2013). Natural RNA circles function as efficient microRNA sponges. Nature 495, 384-388. doi: 10.1038/nature11993

Huang, S., Li, X., Zheng, H., Si, X., Li, B., Wei, G., et al. (2019). Loss of SuperEnhancer-Regulated circRNA Nfix Induces Cardiac Regeneration After Myocardial Infarction in Adult Mice. Circulation 139, 2857-2876. doi: 10.1161/CIRCULATIONAHA.118.038361

Jeck, W. R., Sorrentino, J. A., Wang, K., Slevin, M. K., Burd, C. E., Liu, J., et al. (2013). Circular RNAs are abundant, conserved, and associated with ALU repeats. RNA 19, 141-157. doi: 10.1261/rna.035667.112
Keiner, M., Sander, A., Wirth, K., and Schmidtbleicher, D. (2013). Is there a difference between active and less active children and adolescents in jump performance? J. Strength Cond. Res. 27, 1591-1596. doi: 10.1519/ JSC.0b013e318270fc99

Khalil, A. M., Guttman, M., Huarte, M., Garber, M., Raj, A., Rivea Morales, D., et al. (2009). Many human large intergenic noncoding RNAs associate with chromatin-modifying complexes and affect gene expression. Proc. Natl. Acad. Sci. U.S.A. 106, 11667-11672. doi: 10.1073/pnas.0904715106

Koh, W., Pan, W., Gawad, C., Fan, H. C., Kerchner, G. A., Wyss-Coray, T., et al. (2014). Noninvasive in vivo monitoring of tissue-specific global gene expression in humans. Proc. Natl. Acad. Sci. U.S.A. 111, 7361-7366. doi: 10.1073/pnas.1405528111

Kowal, J., Arras, G., Colombo, M., Jouve, M., Morath, J. P., Primdal-Bengtson, B., et al. (2016). Proteomic comparison defines novel markers to characterize heterogeneous populations of extracellular vesicle subtypes. Proc. Natl. Acad. Sci. U.S.A. 113, E968-E977. doi: 10.1073/pnas.1521230113

Kumarswamy, R., Bauters, C., Volkmann, I., Maury, F., Fetisch, J., Holzmann, A., et al. (2014). Circulating long noncoding RNA, LIPCAR, predicts survival in patients with heart failure. Circ. Res. 114, 1569-1575. doi: 10.1161/ CIRCRESAHA.114.303915

Lawson, C., Vicencio, J. M., Yellon, D. M., and Davidson, S. M. (2016). Microvesicles and exosomes: new players in metabolic and cardiovascular disease. J. Endocrinol. 228, R57-R71. doi: 10.1530/JOE-15-0201

Li, P., Chen, S., Chen, H., Mo, X., Li, T., Shao, Y., et al. (2015). Using circular RNA as a novel type of biomarker in the screening of gastric cancer. Clin. Chim. Acta 444, 132-136. doi: 10.1016/j.cca.2015.02.018

Li, H., Xu, J. D., Fang, X. H., Zhu, J. N., Yang, J., Pan, R., et al. (2020). Circular RNA circRNA_000203 aggravates cardiac hypertrophy via suppressing miR26b-5p and miR-140-3p binding to Gata4. Cardiovasc. Res. 116, 1323-1334. doi: $10.1093 / \mathrm{cvr} / \mathrm{cvz} 215$

Liang, D., and Wilusz, J. E. (2014). Short intronic repeat sequences facilitate circular RNA production. Genes Dev. 28, 2233-2247. doi: 10.1101/ gad.251926.114

Lim, T. B., Aliwarga, E., Luu, T. D. A., Li, Y. P., Ng, S. L., Annadoray, L., et al. (2019). Targeting the highly abundant circular RNA circSlc8al in cardiomyocytes attenuates pressure overload induced hypertrophy. Cardiovasc. Res. 115, 1998-2007. doi: 10.1093/cvr/cvz130

Liu, X., Tong, Z., Chen, K., Hu, X., Jin, H., and Hou, M. (2018). The Role of miRNA-132 against Apoptosis and Oxidative Stress in Heart Failure. BioMed. Res. Int. 2018, 3452748. doi: 10.1155/2018/3452748

Liu, X., Wang, M., Li, Q., Liu, W., Song, Q., and Jiang, H. (2020). CircRNA ACAP2 induces myocardial apoptosis after myocardial infarction by sponging miR-29. Minerva Med. doi: 10.23736/S0026-4806.20.06600-8

Maas, S. L. N., Breakefield, X. O., and Weaver, A. M. (2017). Extracellular Vesicles: Unique Intercellular Delivery Vehicles. Trends Cell Biol. 27, 172-188. doi: 10.1016/j.tcb.2016.11.003

Mahmoud, A. I., Kocabas, F., Muralidhar, S. A., Kimura, W., Koura, A. S., Thet, S., et al. (2013). Meis1 regulates postnatal cardiomyocyte cell cycle arrest. Nature 497, 249-253. doi: 10.1038/nature12054

Masson, S., Batkai, S., Beermann, J., Bar, C., Pfanne, A., Thum, S., et al. (2018). Circulating microRNA-132 levels improve risk prediction for heart failure hospitalization in patients with chronic heart failure. Eur. J. Heart Fail 20, 78 85. doi: 10.1002/ejhf.961

Medvedeva, E. A., Berezin, Ii., and Shchukin, Y. V. (2017). [Galectin-3, Markers of Oxidative Stress and Renal Dysfunction in Patients With Chronic Heart Failure]. Kardiologiia 57, 46-50. doi: 10.18565/ cardio.2017.3.46-50

Memczak, S., Jens, M., Elefsinioti, A., Torti, F., Krueger, J., Rybak, A., et al. (2013). Circular RNAs are a large class of animal RNAs with regulatory potency. Nature 495, 333-338. doi: 10.1038/nature11928

Memczak, S., Papavasileiou, P., Peters, O., and Rajewsky, N. (2015). Identification and Characterization of Circular RNAs As a New Class of Putative Biomarkers in Human Blood. PloS One 10, e0141214. doi: 10.1371/ journal.pone. 0141214

Metra, M., and Teerlink, J. R. (2017). Heart failure. Lancet 390, 1981-1995. doi: 10.1016/S0140-6736(17)31071-1

Morgan, J. P., Erny, R. E., Allen, P. D., Grossman, W., and Gwathmey, J. K. (1990). Abnormal intracellular calcium handling, a major cause of systolic and 
diastolic dysfunction in ventricular myocardium from patients with heart failure. Circulation 81, III21-III32. doi: 10.1016/0021-9150(90)90061-M

Naji, P., Shah, S., Svensson, L. G., Gillinov, A. M., Johnston, D. R., Rodriguez, L. L., et al. (2017). Incremental Prognostic Use of Left Ventricular Global Longitudinal Strain in Asymptomatic/Minimally Symptomatic Patients With Severe Bioprosthetic Aortic Stenosis Undergoing Redo Aortic Valve Replacement. Circ. Cardiovasc. Imaging 10, e005942. doi: 10.1161/CIRCIMAGING.116.005942

Nevo, I., Erlichman, M., Algur, N., and Nir, A. (2011). N-terminal pro B-type natriuretic peptide levels in infants and children with acute non-cardiac diseases. Isr. Med. Assoc. J. 13, 420-424. doi: 10.1055/s-0031-1281551

Ovchinnikova, E. S., Schmitter, D., Vegter, E. L., Ter Maaten, J. M., Valente, M. A., Liu, L. C., et al. (2016). Signature of circulating microRNAs in patients with acute heart failure. Eur. J. Heart Fail 18, 414-423. doi: 10.1002/ejhf.332

Petkovic, S., and Muller, S. (2015). RNA circularization strategies in vivo and in vitro. Nucleic Acids Res. 43, 2454-2465. doi: 10.1093/nar/gkv045

Ponikowski, P., Voors, A. A., Anker, S. D., Bueno, H., Cleland, J. G. F., Coats, A. J. S., et al. (2016). 2016 ESC Guidelines for the diagnosis and treatment of acute and chronic heart failure: The Task Force for the diagnosis and treatment of acute and chronic heart failure of the European Society of Cardiology (ESC)Developed with the special contribution of the Heart Failure Association (HFA) of the ESC. Eur. Heart J. 37, 2129-2200. doi: 10.1093/eurheartj/ehw128

Pouleur, A. C., Barkoudah, E., Uno, H., Skali, H., Finn, P. V., Zelenkofske, S. L., et al. (2010). Pathogenesis of sudden unexpected death in a clinical trial of patients with myocardial infarction and left ventricular dysfunction, heart failure, or both. Circulation 122, 597-602. doi: 10.1161/CIRCULATIONAHA.110.940619

Ramachandran, S., Lowenthal, A., Ritner, C., Lowenthal, S., and Bernstein, H. S. (2017). Plasma microvesicle analysis identifies microRNA 129-5p as a biomarker of heart failure in univentricular heart disease. PloS One 12, e0183624. doi: 10.1371/journal.pone.0183624

Reiken, S., Wehrens, X. H., Vest, J. A., Barbone, A., Klotz, S., Mancini, D., et al. (2003). Beta-blockers restore calcium release channel function and improve cardiac muscle performance in human heart failure. Circulation 107, 24592466. doi: 10.1161/01.CIR.0000068316.53218.49

Salgado-Somoza, A., Zhang, L., Vausort, M., and Devaux, Y. (2017). The circular RNA MICRA for risk stratification after myocardial infarction. Int. J. Cardiol. Heart Vasc. 17, 33-36. doi: 10.1016/j.ijcha.2017.11.001

Salzman, J., Chen, R. E., Olsen, M. N., Wang, P. L., and Brown, P. O. (2013). Celltype specific features of circular RNA expression. PloS Genet. 9, e1003777. doi: 10.1371/journal.pgen.1003777

Scali, M. C., Simioniuc, A., Dini, F. L., and Marzilli, M. (2014). The potential value of integrated natriuretic peptide and echo-guided heart failure management. Cardiovasc. Ultrasound 12, 27. doi: 10.1186/1476-7120-12-27

Sonnenschein, K., Wilczek, A. L., De Gonzalo-Calvo, D., Pfanne, A., Derda, A. A., Zwadlo, C., et al. (2019). Serum circular RNAs act as blood-based biomarkers for hypertrophic obstructive cardiomyopathy. Sci. Rep. 9, 20350. doi: 10.1038/ s41598-019-56617-2

Sun, B., Meng, M., Wei, J., and Wang, S. (2020). Long noncoding RNA PVT1 contributes to vascular endothelial cell proliferation via inhibition of miR190a-5p in diagnostic biomarker evaluation of chronic heart failure. Exp. Ther. Med. 19, 3348-3354. doi: 10.3892/etm.2020.8599

Sun, L. Y., Zhao, J. C., Ge, X. M., Zhang, H., Wang, C. M., and Bie, Z. D. (2020). Circ_LAS1L regulates cardiac fibroblast activation, growth, and migration through miR-125b/SFRP5 pathway. Cell Biochem. Funct. 38, 443-450. doi: $10.1002 / \mathrm{cbf} .3486$

Sun, Y., Jiang, X., Lv, Y., Liang, X., Zhao, B., Bian, W., et al. (2020). Circular RNA Expression Profiles in Plasma from Patients with Heart Failure Related to Platelet Activity. Biomolecules 10, 187. doi: 10.3390/biom10020187

Takov, K., Yellon, D. M., and Davidson, S. M. (2019). Comparison of small extracellular vesicles isolated from plasma by ultracentrifugation or sizeexclusion chromatography: yield, purity and functional potential. J. Extracell Vesicles 8, 1560809. doi: 10.1080/20013078.2018.1560809

Tan, W. L., Lim, B. T., Anene-Nzelu, C. G., Ackers-Johnson, M., Dashi, A., See, K., et al. (2017). A landscape of circular RNA expression in the human heart. Cardiovasc. Res. 113, 298-309. doi: 10.1093/cvr/cvw250

Tijsen, A. J., Creemers, E. E., Moerland, P. D., De Windt, L. J., Van Der Wal, A. C., Kok, W. E., et al. (2010). MiR423-5p as a circulating biomarker for heart failure. Circ. Res. 106, 1035-1039. doi: 10.1161/CIRCRESAHA.110.218297
Vausort, M., Salgado-Somoza, A., Zhang, L., Leszek, P., Scholz, M., Teren, A., et al. (2016). Myocardial Infarction-Associated Circular RNA Predicting Left Ventricular Dysfunction. J. Am. Coll. Cardiol. 68, 1247-1248. doi: 10.1016/ j.jacc.2016.06.040

Vega, R. B., Harrison, B. C., Meadows, E., Roberts, C. R., Papst, P. J., Olson, E. N., et al. (2004). Protein kinases C and D mediate agonist-dependent cardiac hypertrophy through nuclear export of histone deacetylase 5. Mol. Cell Biol. 24, 8374-8385. doi: 10.1128/MCB.24.19.8374-8385.2004

Vicens, Q., and Westhof, E. (2014). Biogenesis of Circular RNAs. Cell 159, 13-14. doi: 10.1016/j.cell.2014.09.005

Viereck, J., Kumarswamy, R., Foinquinos, A., Xiao, K., Avramopoulos, P., Kunz, M., et al. (2016). Long noncoding RNA Chast promotes cardiac remodeling. Sci. Transl. Med. 8, 326ra322. doi: 10.1126/scitranslmed.aaf1475

Vilades, D., Martinez-Camblor, P., Ferrero-Gregori, A., Bar, C., Lu, D., Xiao, K., et al. (2020). Plasma circular RNA hsa_circ_0001445 and coronary artery disease: Performance as a biomarker. FASEB J. 34, 4403-4414. doi: 10.1096/ fj.201902507R

Wang, K., Liu, F., Zhou, L. Y., Long, B., Yuan, S. M., Wang, Y., et al. (2014). The long noncoding RNA CHRF regulates cardiac hypertrophy by targeting miR489. Circ. Res. 114, 1377-1388. doi: 10.1161/CIRCRESAHA.114.302476

Wang, K., Long, B., Liu, F., Wang, J. X., Liu, C. Y., Zhao, B., et al. (2016). A circular RNA protects the heart from pathological hypertrophy and heart failure by targeting miR-223. Eur. Heart J. 37, 2602-2611. doi: 10.1093/eurheartj/ ehv713

Werfel, S., Nothjunge, S., Schwarzmayr, T., Strom, T. M., Meitinger, T., and Engelhardt, S. (2016). Characterization of circular RNAs in human, mouse and rat hearts. J. Mol. Cell Cardiol. 98, 103-107. doi: 10.1016/j.yjmcc.2016. 07.007

Westholm, J. O., Miura, P., Olson, S., Shenker, S., Joseph, B., Sanfilippo, P., et al. (2014). Genome-wide analysis of drosophila circular RNAs reveals their structural and sequence properties and age-dependent neural accumulation. Cell Rep. 9, 1966-1980. doi: 10.1016/j.celrep.2014.10.062

Wu, W. P., Pan, Y. H., Cai, M. Y., Cen, J. M., Chen, C., Zheng, L., et al. (2020). Plasma-Derived Exosomal Circular RNA hsa_circ_0005540 as a Novel Diagnostic Biomarker for Coronary Artery Disease. Dis. Markers 2020, 3178642. doi: $10.1155 / 2020 / 3178642$

Xia, L., and Song, M. (2020). Role of Non-coding RNA in Diabetic Cardiomyopathy. Adv. Exp. Med. Biol. 1229, 181-195. doi: 10.1007/978-98115-1671-9_10

Xuan, L., Sun, L., Zhang, Y., Huang, Y., Hou, Y., Li, Q., et al. (2017). Circulating long non-coding RNAs NRON and MHRT as novel predictive biomarkers of heart failure. J. Cell Mol. Med. 21, 1803-1814. doi: 10.1111/jcmm.13101

Yancy, C. W., Jessup, M., Bozkurt, B., Butler, J., Casey, D. E.Jr., Colvin, M. M., et al. (2017). 2017 ACC/AHA/HFSA Focused Update of the 2013 ACCF/AHA Guideline for the Management of Heart Failure: A Report of the American College of Cardiology/American Heart Association Task Force on Clinical Practice Guidelines and the Heart Failure Society of America. Circulation 136, e137-e161. doi: 10.1161/CIR.0000000000000509

Yang, Y., Fan, X., Mao, M., Song, X., Wu, P., Zhang, Y., et al. (2017). Extensive translation of circular RNAs driven by N(6)-methyladenosine. Cell Res. 27, 626-641. doi: 10.1038/cr.2017.31

Yu, X., Zou, T., Zou, L., Jin, J., Xiao, F., and Yang, J. (2017). Plasma Long Noncoding RNA Urothelial Carcinoma Associated 1 Predicts Poor Prognosis in Chronic Heart Failure Patients. Med. Sci. Monit. 23, 2226-2231. doi: 10.12659/MSM.904113

Yuan, Y., Du, W., Liu, J., Ma, W., Zhang, L., Du, Z., et al. (2018). Stem CellDerived Exosome in Cardiovascular Diseases: Macro Roles of Micro Particles. Front. Pharmacol. 9, 547. doi: 10.3389/fphar.2018.00547

Yvan, D., and Lu, Z. (2018). Google patent: WO2018220185A1.

Yvan, D., Melanie, V., and Lu, Z. (2017). Google patent: WO2017046203A1.

Zeng, Y., Du, W. W., Wu, Y., Yang, Z., Awan, F. M., Li, X., et al. (2017). A Circular RNA Binds To and Activates AKT Phosphorylation and Nuclear Localization Reducing Apoptosis and Enhancing Cardiac Repair. Theranostics 7, 38423855. doi: $10.7150 /$ thno. 19764

Zhang, Y., Cheng, J., Chen, F., Wu, C., Zhang, J., Ren, X., et al. (2017). Circulating endothelial microparticles and miR-92a in acute myocardial infarction. Biosci. Rep. 37, BSR20170047. doi: 10.1042/BSR20170047 
Zhang, M., Wang, Z., Cheng, Q., Wang, Z., Lv, X., Wang, Z., et al. (2020). Circular RNA (circRNA) CDYL Induces Myocardial Regeneration by ceRNA After Myocardial Infarction. Med. Sci. Monit. 26, e923188. doi: 10.12659/MSM.923188

Zhang, Q., Sun, W., Han, J., Cheng, S., Yu, P., Shen, L., et al. (2020). The circular RNA hsa_circ_0007623 acts as a sponge of microRNA-297 and promotes cardiac repair. Biochem. Biophys. Res. Commun. 523, 993-1000. doi: 10.1016/ j.bbrc.2019.12.116

Zhao, Z., Li, X., Gao, C., Jian, D., Hao, P., Rao, L., et al. (2017). Peripheral blood circular RNA hsa_circ_0124644 can be used as a diagnostic biomarker of coronary artery disease. Sci. Rep. 7, 39918. doi: 10.1038/srep39918
Conflict of Interest: The authors declare that the research was conducted in the absence of any commercial or financial relationships that could be construed as a potential conflict of interest.

Copyright (c) 2020 Sun, Ni, Song and Cao. This is an open-access article distributed under the terms of the Creative Commons Attribution License (CC BY). The use, distribution or reproduction in other forums is permitted, provided the original author(s) and the copyright owner(s) are credited and that the original publication in this journal is cited, in accordance with accepted academic practice. No use, distribution or reproduction is permitted which does not comply with these terms. 